\title{
ELECTRON-OPTICAL AND AUGER ELECTRON SPECTROSCOPY STUDIES OF A ZIRCONIUM CONVERSION COATING ON ALUMINIUM
}

\author{
ELEKTRONSKO-OPTIČNA ŠTUDIJA IN AUGERJEVA \\ ELEKTRONSKA SPEKTROSKOPIJA KONVERZIJSKE PREVLEKE \\ NA OSNOVI CIRKONIJA, NANEŠENE NA ČISTI ALUMINIJ
}

\author{
Adeolu Adesoji Adediran',3, Makanjuola Oki ${ }^{1 *}$, Sarah Abidemi Akintola ${ }^{2}$, \\ Bamidele Ogunsemi ${ }^{1}$, Esther Titilayo Akinlabi ${ }^{3,4}$ \\ ${ }^{1}$ Landmark University, College of Engineering, Department of Mechanical Engineering, Km 4, Ipetu, Omu-Aran, PMB 1001, Ipetu Road, \\ Kwara State, Nigeria \\ ${ }^{2}$ University of Ibadan, Faculty of Technology, Department of Petroleum Engineering, Oduduwa Road, PMB 5116, Ibadan, Oyo State, Nigeria \\ ${ }^{3}$ University of Johannesburg, Faculty of Engineering and the Built Environment, Department of Mechanical Engineering, P. O. Box 524, \\ Auckland Park Campus, 2006, Johannesburg, South Africa \\ ${ }^{4}$ Covenant University, Department of Mechanical Engineering, Km 10 Idi-Iroko Road, Canaanland, Ota, Ogun 112001, Nigeria
}

Prejem rokopisa - received: 2018-09-11; sprejem za objavo - accepted for publication: 2018-10-18

doi:10.17222/mit.2018.197

\begin{abstract}
The techniques of scanning electron microscopy (SEM), transmission electron microscopy (TEM), ultramicrotomy and energy dispersive X-ray analysis (EDX) were employed to examine conversion coatings on aluminium developed from a zirconium nitrate/fluoride solution. The coating developed slowly on a microscopic metal substrate with islands of zirconium-rich centres within the coating matrix. According to the TEM assessment, the coating thickness was $30 \mathrm{~nm}$ for specimens treated for $60 \mathrm{~s}$ and $50 \mathrm{~nm}$ for those treated for $900 \mathrm{~s}$. The population of the zirconium-rich centers ranged from $2.8 \times 10^{12} \mathrm{~m}^{-2}$ to $6 \times 10^{12} \mathrm{~m}^{-2}$ over the treatment period. According to Auger-electron-spectroscopy in-depth analyses, the coating is composed of three diffused layers with an outer region of zirconium oxide followed by a layer of aluminium oxide/hydroxide and an inner layer at the metal/coating interface comprising compounds of aluminium and fluorides. The corrosion-resistance and paint-adhesion characteristics of the zirconium conversion coating are superior to those of bare aluminium.

Keywords: SEM/TEM/EDX, ultramicrotomy, zirconium conversion coating, corrosion
\end{abstract}

Avtorji so uporabili SEM in TEM/EDX tehnike za preiskavo konverzijske prevleke, nastale na podlogi iz tehnično čistega aluminija $\mathrm{z}$ uporabo Zr nitrat/fluoridne raztopine. Prevleka je nastajala počasi na mikroskopski kovinski podlagi s posameznimi središči z Zr bogatih otočkov znotraj matrice prevleke. S TEM ocenjena debelina prevleke je znašala $30 \mathrm{~nm}$ na vzorcih po 60 -sekundni in $50 \mathrm{~nm}$ pri 900 -sekundni obdelavi. Populacija z Zr bogatih otočkov je bila med $2,8 \times 10^{12} \mathrm{~m}^{-2} \mathrm{do} 6 \mathrm{x}^{12} \mathrm{~m}^{-2}$ glede na čas obdelave. Globinska analiza z Augerjevo spektroskopijo je pokazala, da je prevleka sestavljena iz treh difuzijskih plasti: zunanje plasti $\mathrm{Zr}$ oksida, plasti Al oksida/hidroksida ter notranje plasti pri stiku med kovino in prevleko $\mathrm{Z}$ vsebnostjo spojin Al in fluoridov. Korozijska odpornost in adhezijske karakteristike za barve konverzijske prevleke na osnovi Zr so boljše y primerjavi s tistimi na osnovi čistega (neprevlečenega) aluminija.

Ključne besede: SEM/TEM/EDX, ultramikrotomija, konverzijska prevleka na osnovi cirkonija, korozija

\section{INTRODUCTION}

Conversion coatings on aluminium have been in usage for decades to provide additional corrosion resistance and good keying facilities for subsequently applied organic finishes/coatings. However, in the last few decades restrictive legislations have been passed in different countries relating to chromates, the major components of various conversion coating baths. The environmental toxicity and health-related issues of chromates prompted the search for green substitutes that are non-toxic and with an acceptable hazard status. Thus, in the search for a chromate replacement, various researchers examined conversion coatings developed in baths containing permanganate, ${ }^{1-3}$ molybdenum, ${ }^{4-6}$

*Corresponding authors e-mails:

makanjuola.oki@1mu.edu.ng, adediran.adeolu@1mu.edu.ng cerium $^{7-8}$ and zirconium compounds. ${ }^{9,10}$ Though findings suggest that these replacements have a lower corrosion resistance compared to the chromate coatings, they display fairly good paint-adhesion characteristics. Other researchers ${ }^{11-15}$ developed sol-gel coatings as alternatives to chromates with a limited success while the improvements in their corrosion performances were engineered with nano-containerization of the green corrosion inhibitors into the coating fabrics. ${ }^{16-20}$

In order to avoid the contact of chromium compounds with foodstuffs, the canning industries have stringent policies with respect to chromates. The expected corrosion resistance in respect of containers, made mostly of aluminium alloys, is limited to staining protection and enhanced surface for an improved adhesion of lacquer and protective internal coatings. In general, any conversion coating employed in this indus- 
try must display a very good paint-adhesion capability in addition to being colorless. In view of these facts, the current study examines the development of a zirconiumbased conversion coating on super-pure aluminium in order to rank its performance with those of bare-aluminium specimens.

\section{MATERIALS AND METHODS}

\subsection{Materials}

$99.9 \%$ pure aluminium was made into spade-like electrodes. These were electropolished in a perchloric acid/ethanol mixture, rinsed in water and dried. The electropolished electrodes were treated for various times ranging from $30 \mathrm{~s}$ to $900 \mathrm{~s}$ in a zirconium conversion coating solution made up of $4 \mathrm{~g} / \mathrm{L}$ of zirconium nitrate, $2 \mathrm{~g} / \mathrm{L}$ of sodium fluoride and about $1 \mathrm{ml}$ of nitric acid for the $\mathrm{pH}$ adjustment. All the chemicals employed are of an analytical grade from British Drugs House Chemicals, Poole, UK, and doubly distilled water was used throughout.

\subsection{Methods}

From the start of the immersion of the specimens in the coating solution, the potential of each specimen was measured relative to the saturated Calomel electrode and monitored by means of a high-impedance voltmeter and a potentiometric chart recorder. The specimens selected for this study were examined with a Reichart optical microscope and an ISI DS130 scanning electron microscope (SEM) with an elemental analysis of the specimens obtained from the energy dispersive X-ray (EDX) facility attached to the microscope. Ultramicrotomed sections of the selected specimens were obtained in the usual manner ${ }^{21}$ using an LKB Ultratome III 8800 ultramicrotome and thin sections of the specimens with the coatings attached were examined with a Philips 301 transmission electron microscope (TEM). AES depth profiling of the coating obtained with a 300-s immersion in the zirconium solution was obtained with an alternate analysis, in-situ ion-beam etching at approximately $0.3 \mathrm{~nm} / \mathrm{s}$ in a vacuum generator, and Auger electron

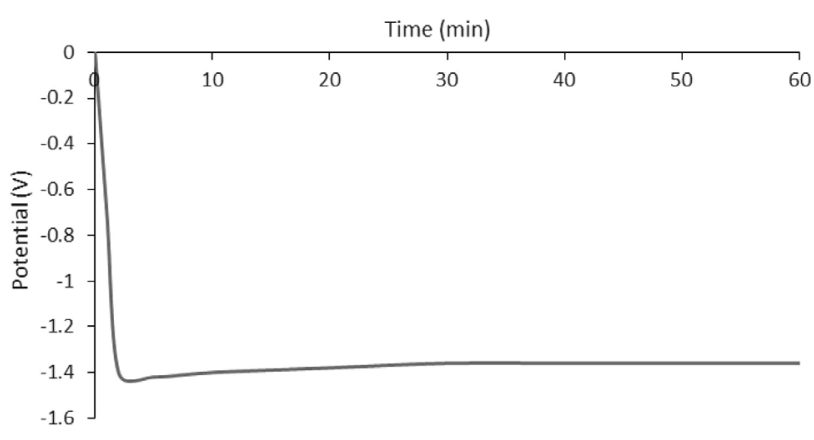

Figure 1: Potential/time measurement for electropolished aluminium in zirconium conversion coating bath spectroscopy with a $3 \mathrm{keV}$ primary electron beam and a beam current of $200 \mu \mathrm{A}$.

A set of specimens, pretreated in a coating bath for $300 \mathrm{~s}$ and bare, electropolished aluminium were coated with a vinyl aerosol clear lacquer in a $20-\mathrm{mL}$ beaker by dipping them into it as near vertical as possible for $90 \mathrm{~s}$. A calibrated permascope (ECS, Fischer's Instrument) was used to determine the thickness of dried lacquer to be $6000 \pm 2000 \mathrm{~nm}$. Individual specimens were exposed at right angle to the base of a humidity cabinet set at $40{ }^{\circ} \mathrm{C}$ and maintained at $100-\%$ relative humidity. At 24-hour intervals and at the end of the exposure, after $100 \mathrm{~h}$, the specimens were dried and examined with optical microscopy, SEM and TEM.

\section{RESULTS AND DISCUSSION}

\subsection{General observations}

The initial visual examination of the specimens treated for various times in the zirconium coating bath showed that the specimens remained reflective after 900 $\mathrm{s}$ of treatment indicating that the as-formed coatings were colorless and relatively thin.

The variation of potential with the treatment time of electropolished aluminium kept in the zirconium conversion coating bath, Figure 1, indicates that upon immersion the potential shifted to negative values and stabilized at about $-1.4 \mathrm{~V}$ after $360 \mathrm{~s}$. This may be related to the feature of the conversion coating formation, where fluoride species in the solution generally activate the substrate prior to the deposition of conversion coating materials, which, in this instance, are likely to be zirconium oxide/hydroxide mixed with aluminium species/compounds.

\subsection{Surface and sectional morphologies of as-formed conversion coatings}

The scanning-electron micrographs of the specimens treated for 30-900 s appeared relatively featureless, yet containing particles which increased in population from about $2.8 \times 10^{12} \mathrm{~m}^{-2}$ for a specimen treated for $30 \mathrm{~s}$, Figure $2 \mathbf{a}$, to $15 \times 10^{12} \mathrm{~m}^{-2}$ for a specimen treated for 900 s, Figure $2 \mathbf{b}$.

These particles are zirconium-rich compounds. The EDX attachment to the SEM indicated the presence of
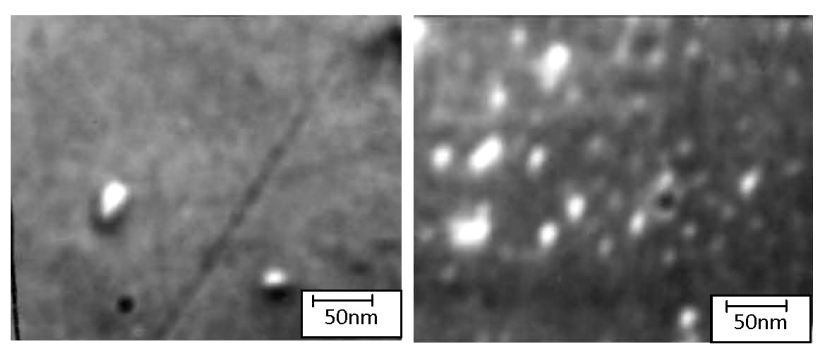

Figures 2: SEM micrographs of aluminium specimens treated for: a) $30 \mathrm{~s}$ and b) $900 \mathrm{~s}$, respectively, in a zirconium conversion coating bath 
(a)

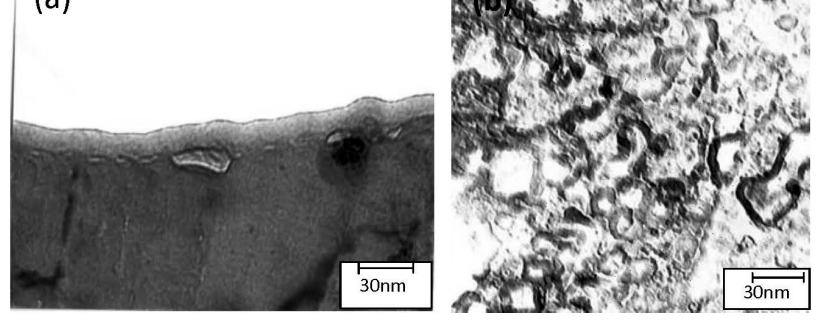

Figure 3: Transmission-electron micrographs of a zirconium conversion coating developed after 300 s showing: a) the ultramicrotomed section and b) stripped coating in plan view

zirconium and aluminium during the spot analyses performed on the clusters of the particles. These are probably hydrated zirconium oxides and/or hydroxides deposited on the microscopic surface of the aluminium substrate during the conversion coating formation. A micrograph of the ultramicrotomed section of the specimen treated for $60 \mathrm{~s}$ revealed that the initial electropolishing film, about $10 \mathrm{~nm}$ in thickness, had been replaced with a thin coating, about $20 \mathrm{~nm}$ in thickness. The zirconium-rich particles observed during the SEM examinations were not revealed, which may have been due to the exact location of the section. The features were not readily resolvable within the coating section, indicating that it is made of micro-crystallites of less than $2.5 \mathrm{~nm}$ in size. The increase in the treatment time to $300 \mathrm{~s}$ caused a coating growth to about $30 \mathrm{~nm}$, as seen in Figure 3a where the coating is displayed at the top of the aluminium substrate spreading towards the bottom of the micrograph. The coating stripped from the substrate with a mercuric chloride solution is displayed in Figure 3b where dark and light materials representing relatively thick and thin coatings can be observed. Unfortunately, the EDX analysis revealed only aluminium; as suggested earlier, the precise locations of the sections excluded the zirconium-rich particles, which may have dropped off into the stripping solution.

A further increase in the coating thickness to about $50 \mathrm{~nm}$ with no change in the morphology of the coating materials were observed for the specimens treated for $900 \mathrm{~s}$ in the conversion coating bath. The coating growth can be described based on the schematic diagrams from Figures $4 \mathbf{a}$ to $\mathbf{4 c}$. The schematic electropolishing film from Figure 4a was described variously elsewhere ${ }^{21}$; the electropolished specimen treated for $60 \mathrm{~s}$ revealed the formation of a coating of about $20 \mathrm{~nm}$ in thickness. Both the metal/coating and the coating/solution interfaces

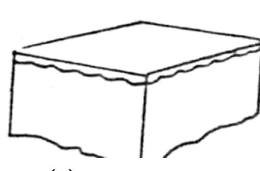

(a)

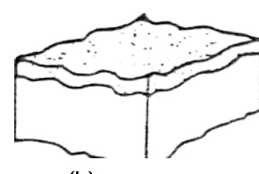

(b)

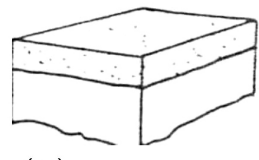

(c)
Figure 4: Schematic representation of the growth of the zirconium conversion coating on aluminium substrate appeared to be undulating and any features of the coating materials were not resolvable, hence they were smaller than $2.5 \mathrm{~nm}$. Further treatment for $300 \mathrm{~s}$ and $900 \mathrm{~s}$ revealed a continuous coating growth to about $30 \mathrm{~nm}$ and $50 \mathrm{~nm}$, respectively. Individual features were still not easily resolved within the coating materials; however, both the metal/coating and the coating/solution interfaces flattened out. This indicates further increases in the development of the colorless zirconium conversion coating on the aluminium substrate.

\subsection{Auger electron spectroscopy (AES) analysis}

The AES surface analysis of the specimen treated for $300 \mathrm{~s}$ in the zirconium coating bath indicated the presence of zirconium, oxygen and fluoride with a very low yield for aluminium. The Auger peak for $\mathrm{Zr}$ appeared at $147 \mathrm{eV}$, which corresponds to zirconium in $\mathrm{ZrO}_{2}$ implying that the coating surface is mostly composed of zirconium oxide with fluoride and some aluminium species..$^{22}$ The deposition of the sparingly soluble zirconium oxide as a result of an increase in the interfacial $\mathrm{pH}$ of the specimen followed the usual activation of the aluminium substrate by fluoride in the coating bath with the attendant anodic dissolution of aluminium and the corresponding cathodic hydrogen evolution reaction in the acidic bath. The AES depth profile of the specimen is displayed in Figure 5 where it can be observed that the intensity of the $\mathrm{Zr}$ yield is at its maximum in the coating materials at the film/solution interface, decreasing rapidly with the etching time, suggesting that it is present mainly in the near-surface regions of the coating. Fluorine has a peak in the outer region of the coating where it may be adsorbed as fluoride species.

However, another peak appeared at $60 \mathrm{~s}$ of etching, indicating that it was involved in the activation of the substrate at the metal/coating interface. The aluminium yield increased from a very low intensity at the coating/ solution interface to its maximum at the metal/coating interface at $60 \mathrm{~s}$ of etching where it remained constant. On the contrary, oxygen in the coating decreased in intensity from the coating/solution interface to the metal/coating interface. In the outer regions of the

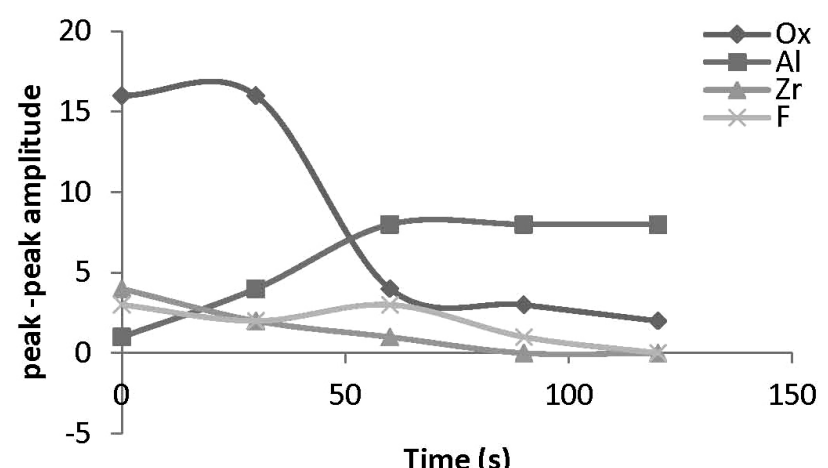

Figure 5: AES depth profile of aluminium specimen treated for $300 \mathrm{~s}$ in a zirconium conversion coating bath 
coating, it is associated with zirconium as $\mathrm{ZrO}_{2}$ and probably as water of hydration. Within the coating, oxygen is likely to be associated with aluminium as $\mathrm{Al}_{2} \mathrm{O}_{3}$ which is corroborated by the shifts of $\mathrm{Al}$ and $\mathrm{O}$ peaks around $1390 \mathrm{eV}$ and $510 \mathrm{eV}$ in the AES spectra. Beyond the 90-s etching time, most of the Auger peaks observed are likely to come from the background noise in the equipment.

From the AES depth-profile analyses, it appears that the outer region of the coating is essentially composed of $\mathrm{ZrO}_{2}$ with some fluoride species occluded within the coating and an underlying coating material that is essentially alumina. However, fluoride is generally present within the coating with peaks at both the coating/ solution and metal/coating interfaces. Thus, the diffuse three-layer coating may be diagrammatically described as displayed in Figure 6, showing the outer $\mathrm{ZrO}_{2}$ at the top of the diagram, laced with $\mathrm{F}^{-}$and $\mathrm{Al}^{3+}$ species. Sandwiched between this outer region and the inner fluoride $\mathrm{Al}^{3+}$-rich coating materials next to the metal/ coating interface, there is the $\mathrm{Al}_{2} \mathrm{O}_{3}$ coating material as indicated by the Auger analyses.

\begin{tabular}{|c|}
\hline $\mathrm{ZrO}_{2} \mathrm{~F}^{-} \mathrm{ZrO}_{2} \mathrm{ZrO}_{2} \mathrm{Al}^{3+} \mathrm{ZrO}_{2} \mathrm{~F}^{-} \mathrm{ZrO}_{2} \mathrm{~F}^{-}$ \\
\hline $\mathrm{Al}_{2} \mathrm{O}_{3} \mathrm{Al}_{2} \mathrm{O}_{3} \mathrm{Al}_{2} \mathrm{O}_{3} \mathrm{Al}^{3+} \mathrm{F}^{-} \mathrm{Al}_{2} \mathrm{O}_{3} \mathrm{Al}_{2} \mathrm{O}_{3}$ \\
\hline $\mathrm{F}^{-} \mathrm{F}^{-} \mathrm{O} \mathrm{Al}^{3+} \mathrm{O} \mathrm{F}^{-} \mathrm{Al}^{3+} \mathrm{O} \mathrm{OF}^{-} \mathrm{F}^{-} \mathrm{Al}^{3+}$ \\
\hline Aluminium substrate \\
\hline
\end{tabular}

Figure 6: Schematic illustration of aluminium substrate carrying zirconium conversion coating

\subsection{Performance of zirconium conversion coating in a $100-\%$ humidity cabinet at $40^{\circ} \mathrm{C}$}

The untreated and unpainted aluminium specimen was severely corroded after $48 \mathrm{~h}$ of exposure in the humidity cabinet whereas the lacquer-coated specimens and the bare conversion-coated specimens did not seem corroded to the naked eye although the lacquer, which must have absorbed some moisture, turned slightly opaque. The lacquer coating formed a barrier between the substrates and the warm, moist environment in the

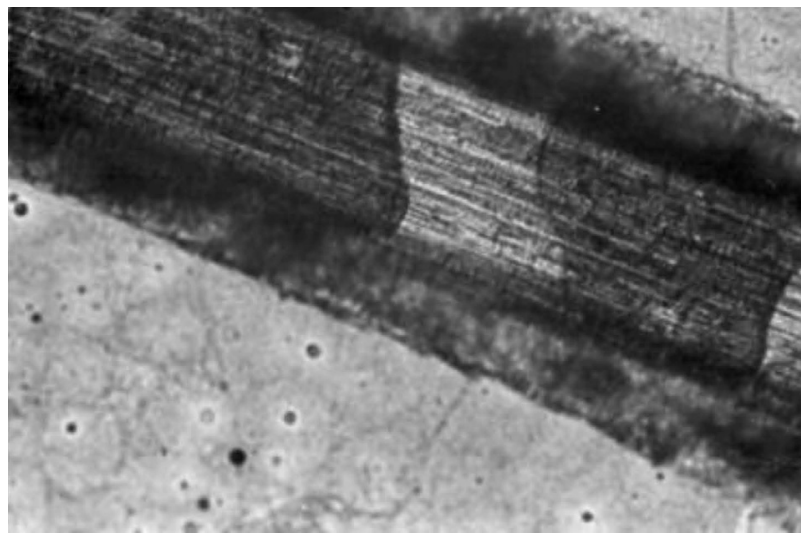

Figure 7: Optical macrograph of an aluminium specimen after exposure in a humidity cabinet for $48 \mathrm{~h}$, a $1000 \times$ magnification

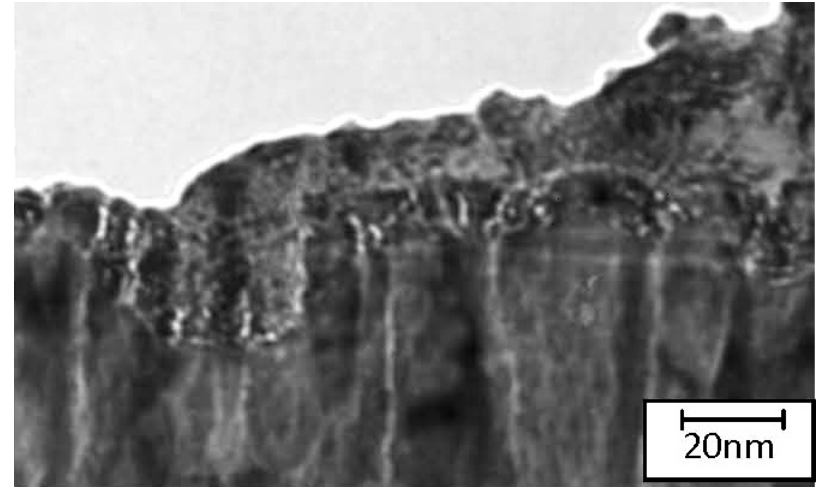

Figure 8: Transmission-electron micrograph of the ultramicrotomed bare aluminium specimen after exposure for $48 \mathrm{~h}$ in a $100-\%$ relative humidity cabinet

cabinet. However, the scratched regions of the specimens revealed some evidence of corrosion when observed with SEM.

Figure 7 shows a macrograph of the bare aluminium specimen after $48 \mathrm{~h}$ of exposure where there are cell-like corrosion products of hydrated $\mathrm{Al}_{2} \mathrm{O}_{3}$ and probably some hydroxides of aluminium on the macroscopic metal surface. The dark spots observed within the corrosion products are likely to be incipient pits that occurred within the flawed regions of the corrosion products. A further examination of an ultramicrotomed section of the corroded region with the transmission electron microscope revealed a featureless corrosion product, about $25 \mathrm{~nm}$ in thickness, at the top, with the aluminium substrate lying at the bottom of the micrograph, Figure 8.

A further exposure of the specimens for $100 \mathrm{~h}$ in the humidity cabinet revealed that the lacquer-coated bare aluminium specimen corroded and the corrosion products formed a cell-like pattern under the lacquer, similar to those observed on the bare aluminium specimen

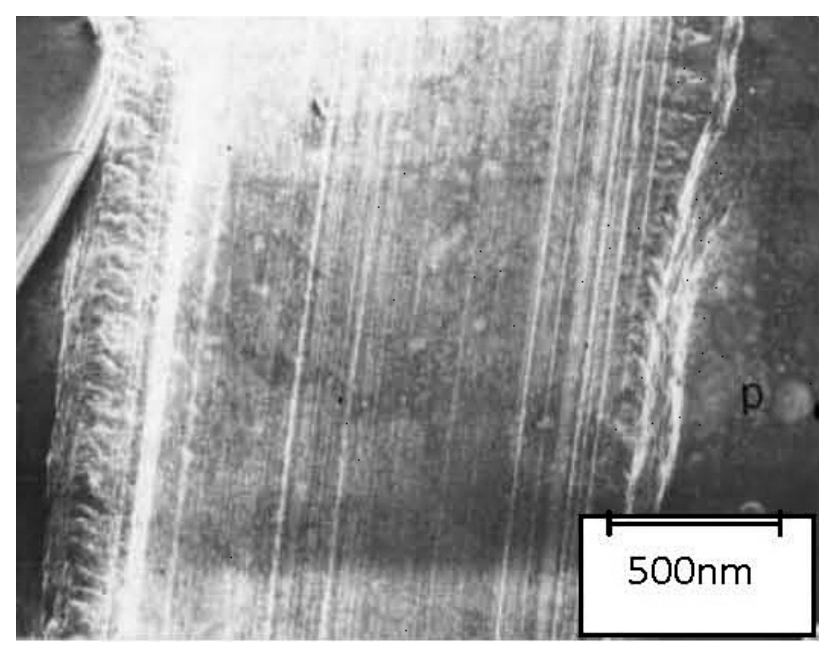

Figure 9: Scanning-electron micrograph of the lacquer-coated barealuminium specimen exposed for $100 \mathrm{~h}$ in the $100-\%$ relative humidity cabinet 


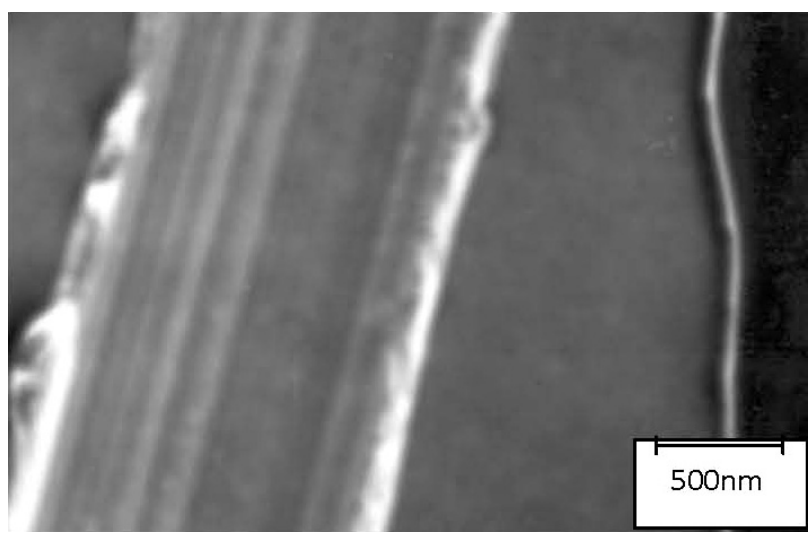

Figure 10: Scanning-electron micrograph of the aluminium specimen with a composite zirconium conversion/lacquer coating after exposure for $100 \mathrm{~h}$ in a 100-\% relative humidity cabinet and application of a tape-adhesion test

exposed for $48 \mathrm{~h}$. The lacquer coating was lifted up at several places, Figure 9, displaying corrosion products marked with $\mathrm{P}$.

The application of an adhesive tape fixed firmly on the specimen (the tape was rapidly pulled off) revealed that the lacquer was completely removed in contrast to the specimen that had a composite zirconium conversion/ lacquer coating, which retained some of the lacquer, Figure 10. Thus, complete adhesion failure of the lacquer was not observed on the zirconium conversioncoated specimen.

This observation is reinforced by the findings of Golrua et al. who concluded that the adhesion strengths of the coatings applied on $\mathrm{Zr}$-treated aluminium samples were greater than those of untreated samples. ${ }^{23}$ However, after an exposure of $100 \mathrm{~h}$, the conversion-coated specimen without a top lacquer coating failed and the examination revealed cracked corrosion products on the aluminium substrate. The conversion coating without a lacquer barrier was compromised after a relatively lengthy period in a high-humidity cabinet.

\section{CONCLUSIONS}

The conversion coating, a colorless material, developed slowly over the treatment period, is composed of featureless micro-crystallites with zirconium oxide in the outermost region followed by an aluminium-oxide-rich coating material, while the region next to the metal/ coating interface is rich in aluminium and fluoride components.

The specimens coated in a zirconium nitrate/fluoride coating bath performed better than bare aluminium when exposed to $40{ }^{\circ} \mathrm{C}$ and $100-\%$ relative humidity in terms of corrosion-resistance and paint-adhesion characteristics.

\section{Acknowledgement}

One of the authors, M. Oki, acknowledges the use of the facilities at the Corrosion and Protection Centre, University of Manchester, UK, and Landmark University, thanking them for their assistance.

\section{REFERENCES}

${ }^{1}$ M. Oki, A. A. Adediran, S. Olayinka, O. Ogunsola, Development and performance of hybrid coatings on aluminium alloy, J. Electrochemical Science and Engineering, 7 (2017) 3, 131-138, doi:10.5599/jese. 347

${ }^{2}$ S. A. Kulinich, M. Farzaneh, X. W. Du, Growth of corrosionresistant manganese oxide coatings on an aluminum alloy, Inorg. Mater., 43 (2007), 956-963, doi:10.1134/S0020168507090087

${ }^{3}$ G. Yogannadan, J. N. Balaraju, V. K. William Grips, The surface and electrochemical analysis of permanganate based conversion coating on alclad and unclad 2024 alloy, Appl. Sur. Sci., 258 (2012) 22, 8880-8888, doi:10.1016/j.apsusc.2012.05.108

${ }^{4}$ C. S. Liang, Z. F. Lv, Y. L. Zhu, S. A. Xu, Molybdate-based conversion treatment for improving the peeling strength between aluminum foil and polypropylene grafted with glycidyl methacrylate, Surf. Coat. Techn., 249 (2014), 1-5, doi:10.1016/j.surfcoat. 2014.03.038

${ }^{5}$ C. M. Zhao, Y. W. Yao, Y. Zhou, Study of formation of molybdate conversion coatings on AZ31 magnesium alloy, The International Journal of Surface Engineering and Coatings, 91 (2013) 6, 330-335, doi:10.1179/0020296713Z.000000000132

${ }^{6}$ Y. Yao, Y. Zhou, L. He, Corrosion behavior of molybdate conversion coatings on AZ31 magnesium alloy in $\mathrm{NaCl}$ solution, Anti-Corrosion Methods and Materials, 60 (2013) 6, 307-311, doi:10.1108/ACMM01-2013-1232

${ }^{7}$ S. J. Hinder, R. Grilli, R. Rustame, W. I. A. Santos, M. A. Baker, I. Costa, A surface analytical investigation of cerium-based conversion coatings deposited onto an AA2024-T3 aluminium alloy cladding layer, Surf. Int. Analy., 46 (2014), 735-739, doi:10.1002/sia.5440

${ }^{8}$ S. Joshi, B. L. Treu, M. J. O'Keefe, W. H. Fahrenholtz, Characterization of cerium-based conversion coatings on Al 7075-T6 deposited from chloride and nitrate salt solutions, J. Electro. Soc., 158 (2011) 3, 88-93, doi:10.1149/1.3537821

${ }^{9}$ H. R. Asemania, P. Ahmadia, A. A. Sarabia, H. E. Mohammadlooa, Effect of zirconium conversion coating: Adhesion and anti-corrosion properties of epoxy organic coating containing zinc aluminum polyphosphate (ZAPP) pigment on carbon mild steel, Progress in Organic Coatings, 94 (2016), 18-27, doi:10.1016/j.porgcoat.2016. 01.015

${ }^{10}$ H. E. Mohammadloo, A. A. Sarabi, R. M. Hosseini, M. Sarayloo, H. Sameie, R. Salimi, A comprehensive study of the green hexafluorozirconic acid-based conversion coating, Prog. Org. Coat., 77 (2014), 322-330, doi:10.1016/j.porgcoat.2013.10.006

${ }^{11}$ M. Oubaha, P. C. R. Varma, B. Duffy, Z. M. Gasem, S. J. Hinder, Development of a novel hybrid aluminum-based sol-gel materials: Application to the protection of AA2024-T3 alloys in alkaline environment, Adv. Mater. Phy. Chem., 4 (2014), 75-84, doi:10.4236/ ampc.2014.45010

${ }^{12}$ N. N. Vovodin, V. N. Balbyshev, M. S. Donley, Investigation of corrosion protection performance of sol-gel coatings on AA2024T3, Prog. Org. Coat., 52 (2005), 28-33, doi:10.1016/j.porgcoat.2004. 05.006

${ }^{13}$ J. Yu, G. Ji, Q. Liu, J. Zhang, Z. Shi, Effect of sol-gel $\mathrm{ZrO}_{2}$ films on corrosion behavior of the 304 stainless steel in coal-gases 


\section{A. A. ADEDIRAN et al.: ELECTRON-OPTICAL AND AUGER ELECTRON SPECTROSCOPY STUDIES ...}

environment at high temperature, Surface and Coatings Technology, 331 (2017), 21-26, doi:10.1016/j.surfcoat.2017.10.037

${ }^{14}$ R. Naderi, M. Fedel, T. Urios, M. Poelman, M. G. Olivier, F. Deflorian, Optimization of silane sol-gel coatings for the protection of aluminium components of heat exchangers, Aluminium Surface Science and Technology, 45 (2013) 10,1457-1466, doi:10.1002/ sia. 5249

${ }^{15}$ B. R. Figueira, I. R. Fontinha, C. J. R. Silva, E. V. Pereira, Hybrid sol-gel coatings: Smart and green materials for corrosion mitigation, Coating, 6 (2016) 12, doi:10.3390/coatings6010012

${ }^{16}$ M. Izadi, T. Shahrabi, B. Ramezanzadeh, Electrochemical investigations of the corrosion resistance of a hybrid sol-gel film containing green corrosion inhibitor-encapsulated nano-containers, Journal of the Taiwan Institute of Chemical Engineers, 81 (2017), 356-372, doi:10.1016/j.jtice.2017.10.039

${ }^{17}$ B. Raezanzadeh, A. Ahmadi, M. Mahdavian, Enhancement of the corrosion protection performance and cathodic delamination resistance of epoxy coating through treatment of steel substrate by a novel nanometric sol-gel based silane composite film filled with functionalized grapheme oxide nano-sheets, Corros. Sci., 109 (2016), 182-205, doi:10.1016/j.corsci.2016.04.004
${ }^{18}$ T. Chen, R. Chen, Z. Jin, J. Liu, Engineering hollow mesoporous silica nano-containers with molecular switches for continuous self-healing anticorrosion coating, Journal of Materials Chemistry A, 3 (2015), 9510-9516, doi:10.1039/c5ta01188d

${ }^{19}$ N. Parhizkar, B. Ramezanzadeh, T. Shahrabia, Enhancement of the corrosion protection properties of a hybrid sol-gel based silane film through impregnation of functionalized graphene oxide nanosheets, Journal of the Electrochemical Society, 164 (2017) 14, C1044-C1058, doi:10.1149/2.1271714jes

${ }^{20}$ J. M. Falcon, F. F. Batista, I. V. Aoki, Encapsulation of dodecylamine corrosion inhibitor on silica nanoparticles, Electrochem. Acta, 124 (2013), 109-118, doi:10.1016/j.electacta.2013.06.114

${ }^{21}$ M. Oki, E. Charles, Chromate conversion coating on Al-0.2wt.\% Fe alloy, Materials Letters, 63 (2009), 1990-1991, doi:10.1016/j.matlet. 2009.06.033

${ }^{22}$ Auger electron spectroscopy handbook, Vacuum generators

${ }^{23}$ S. S. Golru, M. M. Attar, B. Ramezanzadehb, Effects of surface treatment of aluminium alloy 1050 on the adhesion and anticorrosion properties of the epoxy coating, Applied Surface Science, 345 (2015), 360-368, doi:10.1016/j.apsusc.2015.03.148 